\title{
Student Satisfaction through an Adaptation of the SAM Method-An Analysis from Consumption to Post-Consumption in Higher Education Degrees
}

\author{
Iara Margolis \\ ${ }^{1}$ União Brasileira de Faculdades \\ ${ }^{2}$ Escola de Arquitetura, Lab2PT, Universidade do Minho \\ Recife, Brazil \\ e-mail: iaramr@gmail.com
}

\author{
Bernardo Providência \\ Escola de Arquitetura, Lab2PT \\ Universidade do Minho \\ Guimarães, Portugal
}

\begin{abstract}
The higher education market is experiencing a duality between meeting financial and academic goals. In both perspectives, the search for student/consumer satisfaction is a reality. The methods for measuring student satisfaction, in the Brazilian scenario, are mostly based on marketing metrics, without a real understanding of the students' feelings and perceptions. Given this scenario, the question is whether there is a divergence in perception between the student and the former student and if there is any viable technique capable of measuring these issues. In a quantitative survey, with 256 students, 81 former students, and 47 professors, an adaptation of the SAM (Self-Assessment Manikin) scale was carried out, with reason-emotion humanoids and academic stimuli. The main result is that the SAM is a viable, fast and effective model. It addresses institutional technical issues from a personal perspective. Furthermore, the divergence of perception between the former students and the current students was found.
\end{abstract}

Keywords-education; research methodology; SAM; emotion; reason

\section{INTRODUCTION}

There are many different ways to call the current society: "Consumer Society" [1, 2], Liquid Society" [1], "Exaggeration Society" [3], "The Spectacle Society" [4]. Among other possibilities, there is the "Information Society", where knowledge has a market-led, strategic, and economic aspect [5]. The higher education degree is an attractive billionaire market, with international investments [6]. However, there is a conflict in this market that is different from any other: the student. On one hand, they are the customers who maintain the profitability of the business, but, on the other hand, it's them, the students, who have a social responsibility for the medium and long-term [7]. In $p$ rivate educational institutions, it occurs at this moment the trade-off between profitability and the purpose of the socioeducational process [8]. This problem is so serious that research [9] has already demonstrated the indifference towards academic needs before momentary opportunities, creating a duality between short and long-term decisions. In the end, in the near future, the former students will demand the results in the face of educational failures [10].

In addition to this scenario, the process of understanding student satisfaction often uses commercial metrics. In Brazil, out of the 10 largest private educational groups, half of them use the NPS metric (net promoter score) to analyze customer loyalty, and $40 \%$ use a Likert scale based on technical guidelines [11]. One of the criticisms towards the NPS model is the claim of alleged 'peripheral blindness', for conceiving complex scenarios with only one source of analysis [12].

It is important to emphasize that satisfaction is a postconsumption understanding in the face of the relationship between performance and feelings [13]. In addition, the search for customer satisfaction results in collecting data about financial gains [14], understanding of customer behavior and perception, and identification of points of improvement about a product/service [15]. However, making a mistake in the definition of satisfaction indicators implies an error at the bottom of the research. Because there is no ideal scale, there is the possibility of customizing the survey [16].

It is known that emotions and motivations interfere in the learning, teaching, and decision-making process [17]. And the way the method is applied to capture information directly influences decision-making and strategic definitions. Therefore, the process of understanding student satisfaction becomes a short and long-term need.

That said, two questions arise: "In fact, is there a divergence between the perception of student and former student analysis?" and "Is there a tool capable of understanding the student's perception in a less mercantile way, but one that helps the institution to set its goals with short, medium and long-term responsibility?"

Intending to answer these questions, this project aimed to analyze a self-report methodology capable of capturing the student data from a more holistic perspective, seeking a possible solution to the mentioned conflict, but also analyzing if there is a change of perception problem indeed. For that, an adaptation of the SAM (Self-Assessment Manikin) methodology was used in an educational context.

The SAM method uses a bipolar self-report model, through non-verbal pictorial images of humanoids, to evaluate emotional responses to a stimulus. The objective of the initial methodology is to measure pleasure, motivation, and dominance [18], according to Figure 1.

After the stimulus, the respondent marks one of the options, and chooses from negative to positive from the demonstration; the middle score is neutral. On the 9-points scale of the regular SAM, results from 1 to 5.99 (score) are 
considered as non-stimulatory, while from 6 to 9 are highlystimulatory stimuli [19].

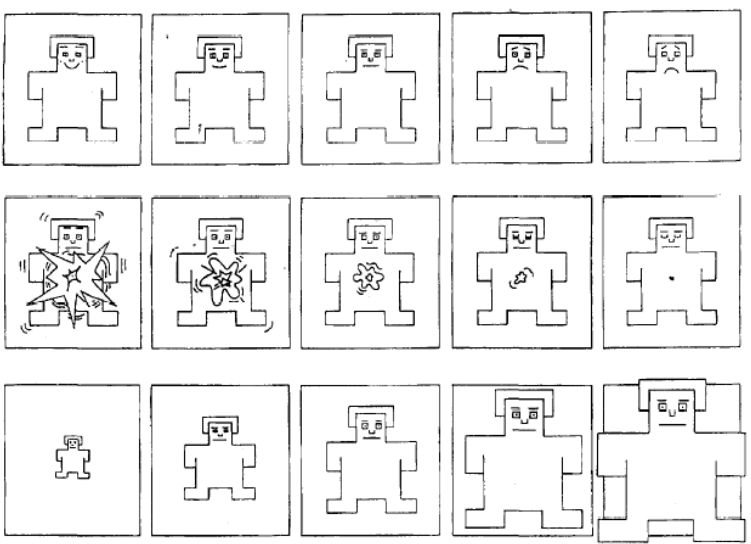

Figure 1. The pictographic dimensions of SAM [18].

It was possible to find some changes in the application model. Starting with the Likert scale of 5 [20] or 9 points [21], applied manually and physically (pencil) or digitally (computers) [18]. In addition, it was possible to find the pictographic representation along with a list of 15 social behaviors [22] or with 18 pairs of goals [18].

There is also the pictographic alteration with the use of three types of humanoids - one of them being the emotionalrational analysis [23], as presented in Figure 2.
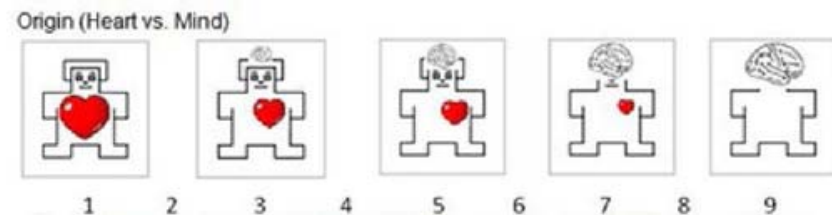

Figure 2. SAM humanoids reason-emotion [23].

This is an inexpensive method that looks at the emotional perspective with simplicity and agility in application and data analysis [18].

\section{METHOD}

\section{A. Methodology Application}

First, an analysis was done with three students about to graduate, who had already gone through almost the entire process. The students had different profiles as learners, but they liked to ask questions and were participative people. After this analysis, it was chosen to adapt the SAM method, on a 9-point scale, using the bipolar reason-emotion image, in the face of unipolar academic stimuli. The reason why a model adaptation to the reason-emotion image was conducted was to understand whether there was a divergence in perception between students and former students. I $t$ was also a way to try to understand how the respondents understood it by themselves as they would answer the questionnaire. In order not to have too many changing variables, it was decided that only one image was going to be used.
The model was applied online, in November of 2019, just before the last exams of the year, in a university center located in Pernambuco, Brazil. By knowing that the educational context has the duality of short and long-term, it was decided to apply the interview to former students; the production engineering course was chosen for being a 5-year course that had a database of former students from the last 5 years. F or also being one of the most traditional courses in the state, for being the second-largest course in terms of students number in the institution, and for having the student database to request participation.

For greater accuracy, the participation of production engineering students was reinforced for a more reliable comparison between the immediate analysis and the analysis in the 'post-consumption', therefore seeking to answer the question of the divergence of perception between the realities.

As a complement, it was also applied with professors, because it was understood that they are one of the key factors for student satisfaction, and to be used as an extra parameter for understanding the perceptions.

The invitation to participate was made by e-mail and WhatsApp groups with voluntary participation; a WhatsApp reinforcement was done only for the former students and professors. The participants' information is presented in Table 1.

TABLE I. PARTICIPANT INFORMATION | SAMPLING

\begin{tabular}{|l|c|c|c|}
\hline \multicolumn{1}{|c|}{ Who } & Participants & Margin of error & $\begin{array}{c}\text { Confidence } \\
\text { level }\end{array}$ \\
\hline Students & 256 & $5,9 \%$ & $95 \%$ \\
\hline Former students & 81 & $10 \%$ & $95 \%$ \\
\hline Professors & 47 & $12 \%$ & $95 \%$ \\
\hline
\end{tabular}

The data was analyzed using median and with the support of SPSS and Microsoft Excel software.

\section{B. The Basis for the Method Adaptation}

Given the suggestion to analyze satisfaction in a scored manner per item [24], and inspired by the SAM method with the use of a list of 15 social behaviors [22] in conjunction with the pictographic model of reason-emotion [23]. The 9point scale was chosen because it presents the intermediate option between images ( 5 images and 4 in between), making each visual dimension its own [25]. In addition, the SAM method has already been used on the 9-point scale in the academic world $[25,26]$. Professor participation and academic stimuli were extracted and based on previous research [27], and validated with students in the pilot survey. The terms were "class" "class participation", "professor", "content", "academic experience", "studying for a subject", "course", "higher education institution", "deepening extraacademic knowledge", "academic engagement", "sense of belonging", "sense of fairness", and "striving to pass (tests and courses)". Finally, a median was used to analyze the data, as it is understood that the format uses a qualitative ordinal scale [28]. 


\section{RESULT}

As a general result, it was possible to notice that everyone involved believed to be more rational than emotional in the analysis of academic stimuli, with a median above 6 . However, professors and former students had a 1degree higher result in the scale, with a perception of them being more rational, as shown in Figure 3.

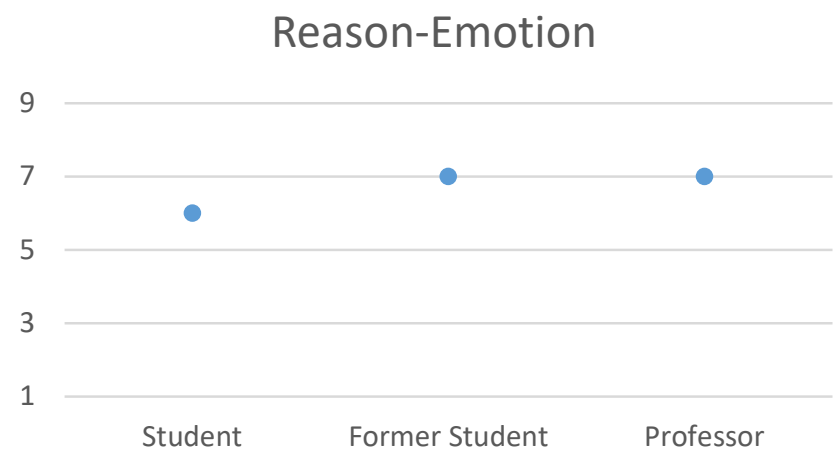

Figure 3. Overall result of all reason-emotion stimuli.

Another way of visualizing the results can be seen in Figure 4, where it demonstrates the median in front of the students' visual analysis. The case demonstrated resulted from the perspective of the students'.
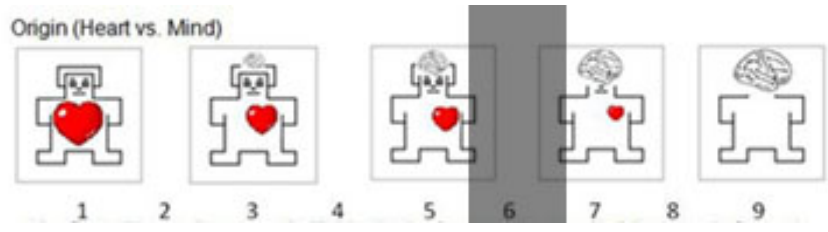

Figure 4. SAM students' result reason-emotion.

\section{A. Stratification by Stimulus-Group}

The former students are the ones who most rationalize issues related to "course" and were the ones who least rationalize over the "higher education institution" topic. It is evident that this evaluation of "course" was the only stimulus that had a median above 7 (with the median, resulting in 8) being the highest activation of the whole questionnaire.

The professors are the ones who rationalize the most over the "effort to pass" issue, and they are the most emotional in the "sense of belonging" matter, with an activation of 5 , which means a balance of reason-emotion before the stimuli. It is noteworthy that this was the only stimulus that had an activation lower than 6 .

The students, in all the stimuli, had their activations equal or lower when compared to former students' and professors' results. However, all responses had an activation above 6, which is considered rational. This means that by comparing them, the students consider themselves most balanced when using reason and emotion, but they still use more reason in the analysis. This data can be visualized in Figure 5.

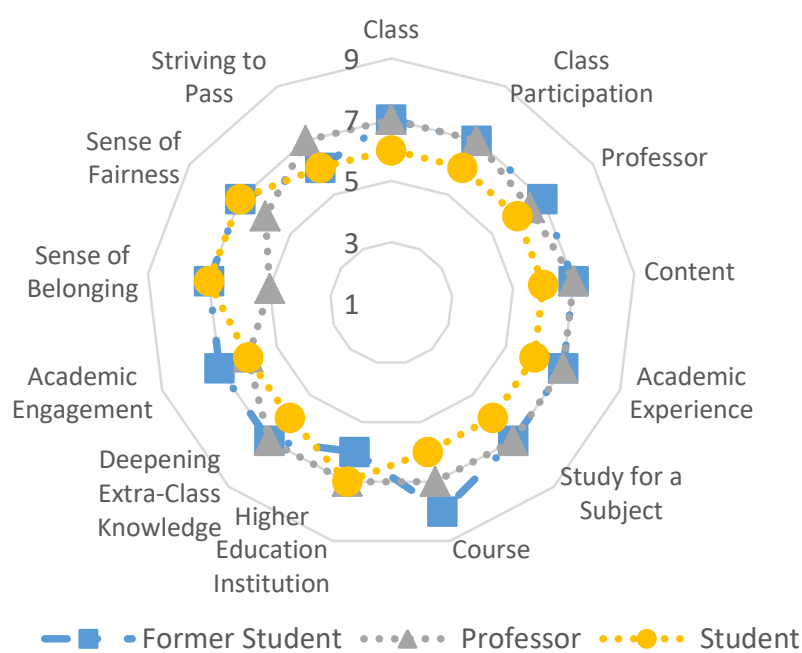

Figure 5. Comparison between Students, Former Studens and Professors.

\section{B. Comparison between students and former students}

By comparing the production engineering course students and former students, it was possible to notice that, in 11 out of 13 stimuli, the former students got results towards a more rational perspective/behavior. The biggest divergences were the "study for a discipline" topic and the "course" matter. The only stimulus that students scored a more rational perspective/behavior was the " higher education institution" topic and the only stimulus that resulted in a tie was the "sense of belonging".

It is important to note that the production engineering students scored two stimuli as neutral (with a median of 5). Those are: "study for a discipline" and "striving to pass". The data can be seen in Figure 6.

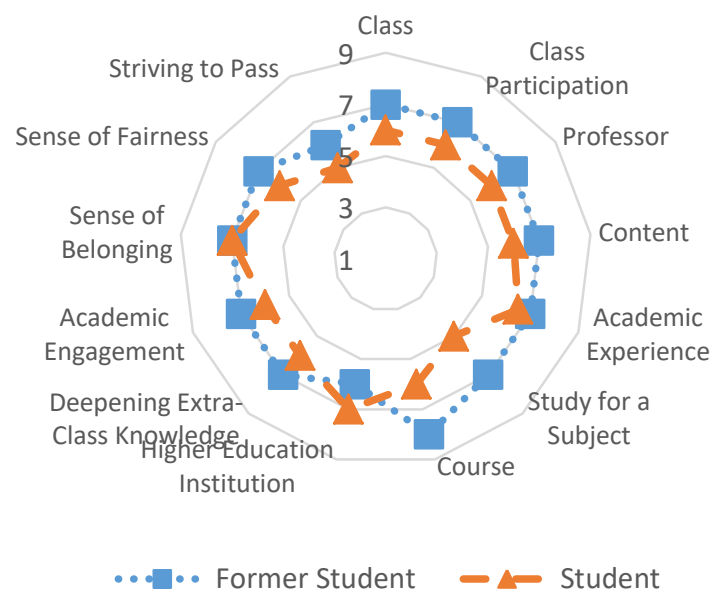

Figure 6. Comparison between former students and students. 


\section{DISCUSSION}

The data treatment converged with what the theory addresses, being easy, cheap, simple, and fast. No difficulty was found in applying the methodology. The results indicate an interesting approach to the difference in perception between students and former students, which converges with the reported dilemma.

Regarding the groups, the former students are the ones who scored and were indicated to be the most rational, followed by the professors, and then by the students. The stimulus "striving to pass" has the least rational activation, followed by "Academic engagement" and then "professor". The analysis of "Sense of belonging" has the highest rational activation, followed by "Higher Education Institution" and then "course".

The SAM method proved to be interesting as it manages to bring technical issues under a more personal approach. This allows decisions to be made in order to improve student satisfaction, but not necessarily being 'indifferent' [10] to the academic interests.

The results of the reason-emotion humanoid allowed us to understand that the interviewees believe they answer in a rational way, which demonstrates a rationalization of the answer, but one wonders if this understanding is driven by feelings and momentary motivations.

\section{CONCLUSION}

The metric for capturing data over student satisfaction is still a challenge, especially from the perspective of meeting short-term demands (commercial) and medium and longterm demands (academic-social). The SAM method proved to be a viable tool capable of performing this analysis, addressing from a personal perspective, some (or any) technical-institutional issues. However, the test was about the perspective of academic analysis of the emotionalrational humanoid. It is suggested the items are redistributed among the different humanoids (motivation, satisfaction, feeling of control, and emotion-ratio). It is also suggested to investigate how the respondent is influenced by his or her emotions and motivations in face of their rationality.

\section{ACKNOWLEDGMENT}

This work was financed by the Project Lab2PT Landscapes, Heritage and Territory laboratory UIDB/04509/2020 through FCT - Fundação para a Ciência e a Tecnologia.

\section{REFERENCES}

[1] Z. BAUMAN, "Vida líquida," 3rd ed., Rio de Janeiro: Jorge Zahar, 2007.

[2] J. BAUDRILLARD, "The consumer society: Myths and structures," London: Sage, 1998.

[3] J. C. CARREIRA, "Da estratégia do anunciante à comunicação publicitária: o caminho do significado," in Hiperpublicidade: Fundamentos e Interfaces, vol. 1, C. PEREZ and I. BARBOSA, São Paulo, Thomson Learning, 2007, pp. 91-123.

[4] G. DEBORD, "A sociedade do Espetáculo", Rio de Janeiro: Contraponto, 2006.
[5] P. DEMO, "Ambivalências da sociedade da informação," Ciência da Informação, vol. 29, n 2, pp. 37-42, 2000.

[6] V. J. MEYER and G. MUNGNOL, "Competição e estratégia no contexto das instituições de ensino superior privadas," Revista Diálogo Educacional, vol. 4, nº 11, pp. 1-13, 2004.

[7] C. H. P. LIMA, G. B. PEREIRA and A. VIEIRA, "Papéis sociais no ensino superior: Aluno-cliente, Professor-gerente-educador, instituição de ensino-mercantil," Ciências da Administração, vol. 8, ${ }^{\circ}$ 15, pp. 2-227, 2006.

[8] V. SGUISSARDI, "Modelo de expansão da educação superior no Brasil: predomínio privado/mercantil e desafios para a regularização e a formação unviersitária," Educação e Sociedade, vol. 29, n 105, pp. 991-1022, 2008.

[9] S. ARONOWITZ and H. A. GIROUX, "The corporate university and the politics of education," The educational forum, vol. $64, \mathrm{n}^{\circ} 4$, pp. 332-339, 2008.

[10] E. MARK, "Student satisfaction and the costumer focus in higher education," Journal of Higher Education Policy Management, vol. 35, $\mathrm{n}^{\mathrm{o}}$ 1, pp. 2-10, 2013.

[11] I. M. RIBEIRO, "Mapeamento da hedonomia e das experiências emocionais: A percepção do aluno no ensino superior sob a perspectiva do design emocional", Recife: Universidade Federal de Pernambuco, 2020, 472p.

[12] T. L. KEININGHAM, L. AKSOY, B. COOIL, T. W. ANDREASSEN and L. WILLIAMS, "A holistic examination of Net Promoter," Database Marketing \& Customer Strategy Management, vol. 15, nº 2, pp. 79-90, 2008.

[13] R. D. BLACKWELL, P. W. MINIARD and J. F. ENGEL, Comportamento do Consumidor, São Paulo: Cengage, 2008.

[14] F. F. REICHHELD and W. E. SASSER, "Zero defections: quality comes to services," Harward Business Review, vol. 68, pp. 105-111, 1990.

[15] F. LARENTIS, C. P. GIACOMELlO and M. E. CAMARGO, "Análise da importância em pesquisas de satisfação através da regressão múltipla: estudo do efeito de diferentes pontos de escala," Revista de Administração da PUCRS, vol. 23, n 3, pp. 258-269, 2012.

[16] C. A. V. ROSSI and L. A. SLONGO, "Pesquisa de satisfação de clientes: o estado-da-arte e proposição de um método brasileiro," Revista de Administração Contemporânea, vol. 2, nº 1, pp. 101-125, 1998

[17] J. G. O. BROCKINGTON, "Neurociência e Educação: Investigando o papel da emoção na aquisição e uso do conhecimento científico," São Paulo: Universidade de São Paulo, 2011, 200p.

[18] M. M. BRADLEY and P. J. LANG, "Measuring Emotion: The SelfAssessment Manikin and The Semantic Differential," Journal of Behavior Therapy and Experimental Psychiatry, vol. 25, n 1, pp. 4959, 1994.

[19] R. F. SANTOS, "Abordagem experimental no estudo das emoções e falsas memórias," Pontifica Universidade Católica do Rio Grande do Sul, Porto Alegre, 2006, 85p.

[20] B. GEETHANJALI, K. ADALARASU, A. HEMAPRABA, S. PRAVIN KUMAR and R. RAJASEKERAN, "Emotion analysis using SAM (Self-Assessment Manikin) scale," Biomedical Research, pp. 18-24, 2017.

[21] L. M. CASTELHANO and L. WAHBA, "Respostas Emocionais de Médicos aos Estímulos Afetivos do International Affective Picture System (IAPS)," Revista Brasileira de Educação Médica, vol. 43, nº 3, pp. 46-53, 2019.

[22] S. PINHEIROS, F. CARDOSO and P. RIBEIRO, "Violência, erótica e julgamentos de generosidade: Um estudo piloto," Revista E-Psi, vol. 8, no 1 , pp. 35-49, 2019.

[23] K. K. IMBIR, "Affective norms for 718 polish short texts (ANPST): dataset with affective ratings for valence, arousal, dominance, origin, subjective significance and source dimensions," Frontiers in Psychology, vol. 7, pp. 1-5, 2016. 
[24] R. L. OLIVER, "Satisfaction: a behavioral perspective on the consumer," New York: Sharpe, 2010.

[25] C. H, KRISTENSEN, C. F. GOMES, A. R. JUSTO and VIEIRA, K. "Normas brasileiras para o affective norms for english words," Trends Psychiatry Psychother, vol. 33, nº 3, pp. 135-146, 2011.

[26] A. L. R. AGUIRRE. "Viés de atenção para pistas relacionadas com alimentos saudáveis e não saudáveis entre crianças com diferentes pesos ao nascer." Universidade Federal do Rio Grande do Sul, Porto Alegre, 2016, $155 \mathrm{p}$.

[27] I. M. RIBEIRO, W. F. M. CORREIA and. F. CAMPOS, "Setores acadêmicos que interferem na satisfação do aluno no ensino superior," Acta Scientiarum. Education, vol. 43, n ${ }^{\circ}$ 1, p. e50121, 2021.

[28] P. BELFIORE, "Estatística aplicada a administração, contabilidade e economia com Excel e SPSS,” Rio de Janeiro: Elsevier, 2015. 